\title{
MOTHER TONGUE DEVELOPMENT IN BILINGUAL PROGRAMS TYPE CLIL IN SECONDARY SCHOOL: A COMPARATIVE STUDY ON WRITTEN PRODUCTION ${ }^{1}$
}

\author{
EL DESARROLLO DE LA LENGUA MATERNA EN PROGRAMAS \\ BILINGÜES TIPO AICLE: UN ESTUDIO COMPARATIVO SOBRE LA \\ PRODUCCIÓN ESCRITA.
}

\author{
ESTHER NIETO \\ Universidad de Castilla-La Mancha \\ Esther.Nieto@uclm.es
}

\begin{abstract}
The aim of this paper is to determine whether the acquisition of written production in the mother tongue (L1) is affected by CLIL (Content and Language Integrated Learning), as a consequence of the fact that less school time is devoted to academic exposure to the L1 in this type of bilingual programs consisting of delivering some content subjects, such as Science, Maths or Art in a second language instead of in the mother tongue. For this purpose, a large-scale study was conducted in Castilla-La Mancha (Spain). Written productions in L1 of CLIL and non-CLIL secondary school students aged 13-14. $(\mathrm{n}=4,675)$ were compared, having into account six written production areas: (1) planning strategies, (2) use of text typologies, (3) expressive richness, (4) use of written vocabulary, (5) use of grammatical structures, and (6) spelling and punctuation. Results showed that, although CLIL students had more limited exposure to L1 compared to their non-CLIL counterparts, they significantly outperformed them in all areas of written production under consideration, and the greatest differences were observed in the most demanding tasks.
\end{abstract}

Keywords: CLIL, bilingual education, written production, mother tongue, Secondary Education.

${ }^{1}$ Esta investigación se circunscribe en el desarrollo del Proyecto denominado: "Attention to Diversity in Bilingual Education: a Comparative Study in Monolingual Contexts". Referencia: RTI2018-093390-B-I00 


\section{RESUMEN}

El objetivo de este trabajo es determinar si la adquisición de producción escrita en la lengua materna (L1) se ve afectada por AICLE (Aprendizaje Integrado de Contenido y Lengua), como consecuencia del hecho de que se dedica menos tiempo escolar a la exposición académica a la L1 en este tipo de programas bilingües que consisten en impartir algunas materias de contenido, como Ciencias, Matemáticas o Arte en un segundo idioma, en lugar de hacerlo en la lengua materna. Para ello, se realizó un estudio a gran escala en Castilla-La Mancha (España). Se compararon las producciones escritas en L1 de alumnos de secundaria AICLE y no-AICLE de 13 a 14 años $(\mathrm{n}=4,675)$ teniendo en cuenta seis áreas de producción escrita: (1) estrategias de planificación, (2) uso de tipologías de texto, (3) riqueza expresiva, (4) uso de vocabulario escrito, (5) uso de estructuras gramaticales, y (6) ortografía y puntuación. Los resultados mostraron que, aunque los estudiantes de CLIL tuvieron una exposición más limitada a la L1 en comparación con sus compañeros no-AICLE, los superaron significativamente en todas las áreas de producción escrita consideradas, y las mayores diferencias se observaron en las tareas más exigentes.

Palabras clave: AICLE, educación bilingüe, producción escrita, lengua materna, Educación Secundaria.

Recibido: 28/05//2020. Aceptado: 05/11/2020.

\section{INTRODUCTION}

The globalization of most economic, academic and social activities poses a new challenge for individuals and educational institutions: learning foreign languages. Within this backdrop, after the success of the Canadian immersion programs, in the last decades of the twentieth century, multiple bilingual education programs have become prevalent in second language acquisition (SLA) throughout the world, as models capable of delivering effective language learning methodologies.

Within European Union, language learning has been considered a fundamental instrument for promoting cohesion, economic development, integration, collaboration and mobility among member states. Therefore, European institutions have supported implementation of bilingual education and in the early 1990s, the acronym CLIL (Content and Language Integrated Learning) was coined. Since then, this methodology has become ever more popular both inside and outside Europe. Its potential lies in its open and non-restrictive nature, since, from its inception, CLIL was conceived as an umbrella term (Dalton-Puffer et al., 2010) for covering an enormous variety of practices in which an additional/ second/foreign language is used for teaching curricular subjects, such as Natural Science, History, Mathematics or Art, for example. 
The popularity of CLIL is also in concomitance with the limited success of traditional courses in foreign language teaching for extending communicative skills in learners (Fernández-Fontecha, 2010). CLIL therefore has become "the potential lynchpin to counter Europe's deficient language standards" (PérezCañado and Ráez 2015), "the ultimate opportunity to practice and improve a foreign language" (Pérez-Vidal, 2013: 59) and "a lever for change and success in language learning" (Pérez-Cañado and Ráez, 2015:1). Unlike in traditional foreign language teaching, CLIL provides a learning scenario that replicates the conditions in which the mother tongue is acquired, since language is learned while also learning contents (Coyle et al., 2010). In addition, the focus on meaning with CLIL, in contrast to the focus on form provided in traditional foreign language teaching, helps learning be more communicative and natural, and contributes to lowering the affective filter (Krashen, 1988).

Thus, CLIL has been considered to be both an efficient approach to language learning (Nieto, 2016a, 2018a; Ruiz de Zarobe, 2015) and an "awesome innovation" in education (Tobin and Abello-Contesse, 2013: 224), since gains in language learning do not seem to be detrimental to assimilating content (Bergroth 2006; Grisaleña, et al., 2009; Madrid, 2011; Nieto and Hill, 2019; Stohler, 2006). Additionally, this integrated methodology seems to enhance acquisition of cross-curricular competences (Nieto, 2012, 2016b, 2018b), and to positively affect motivation (Navarro et al., 2018), even in contexts of minimal L2 input (García-Fernández et al., 2017).

The effectiveness of CLIL programs has been measured so far mainly in terms of L2 acquisition, and comparatively, literacy development in the mother tongue has drawn much less attention of researchers. However, this is not a minor issue, considering that CLIL implies less academic exposure to the mother tongue, since it provides instruction in school subjects in a second language (L2), as a way of increasing exposure to the target language within school hours. This fact can affect the acquisition of written skills in L1, since literacy in the mother tongue is acquired at school, not only in the language classroom, but also in the rest of the school subjects. In addition, written skills are crucial to succeed at school, particularly written production, since written exams and written essays in L1 are the most important academic instruments at secondary school for evaluating whether knowledge in most curricular subjects has been acquired. For this reason, Sierra et al. (2011: 320) underscore that mother tongue development in CLIL programs "deserves further scrutiny". Against this backdrop this article is devoted to exploring how the restriction on the use of the mother tongue CLIL implies, may affect development of written production skills of CLIL secondary school students in their L1.

This study is relevant because (i) it provides evidence in a little researched area, such as acquisition of the mother tongue in CLIL programs, and particularly 
written production, and aspect highly overlooked by researchers so far (ii) the data sample of this study is extensive, and (iii) the research was carried out in CastillaLa Mancha, a monolingual Spanish autonomous community where empirical research conducted to date is scarce.

This paper is organized as follows: after the literature review on the impact of CLIL on the acquisition of the mother tongue, the objectives, sample, instruments and results of this research will be expounded. In the final sections, these results will be discussed within the framework of prior research.

\section{LITERATURE REVIEW. RESEARCH ON THE ACQUISITION OF L1 IN BILINGUAL EDUCATION}

One of the main worries stakeholders have in bilingual programs with a very limited school presence of the L1 in favour of the L2 (such as in Canadian immersion) is precisely to check that the development of academic skills in that mother tongue is not negatively affected.

In this vein, results of research on Canadian immersion programs revealed a negative effect on literacy in the L1 after year 3 of primary education when $100 \%$ of the school subjects were taught in the L2 (Swain and Lapkin, 1982). However, 2 years after the introduction of the instruction of some subjects in the L1, immersion students caught up to their peers who were educated entirely in L1 (Genesee, 2007; Lapkin et al., 2003). This levelling would happen so fast because, according to Cummins' (1979) theory on Common Underlying Proficiency (CUP), and Genesse and Jared's (2008) transfer hypothesis, the language skills and language knowledge acquired would be applied and transferred to all the languages L1, L2, L3 etc. learners are exposed to.

In contrast to these extensive evaluations carried out in Canada and US to determine the impact of immersion programs on the development of the L1, more research is needed to ascertain the effect of CLIL on mother tongue acquisition. According to Pérez-Cañado (2012:318) research results into Canadian and North-American immersion "cannot be simply transferred or transposed to the European scenario", mainly due to a number of dissimilarities between these types of bilingual programs. Lasagabaster and Sierra (2009) listed these main differences as follows: the target language in immersion is spoken locally, while in CLIL is usually a foreign language; immersion teachers are usually native speakers, whereas in CLIL these are foreign speakers of the second language; and in immersion, the objective is for the students to acquire native-like proficiency, while in CLIL is to reach a B1 or B2 level of the CEFR (Common European Framework of Reference for Languages) by the end of secondary education.

Studies on the effect of CLIL on acquisition of the mother tongue were initially 
carried out in Belgium and Finland, on bilingual education programs in which a high percentage of the curriculum (between 50 and $75 \%$ ), was taught in a second language.

In Belgium, Lecocq et al. (2004) compared oral and written comprehension and expression in the mother tongue (French) of primary school students in regular and bilingual programs (in which Dutch and French were used to teach contents). The authors concluded that both groups acquired their mother tongue to the same extent, and differences, if any, favored the latter group. Further studies carried out in the same setting confirmed this finding (Van de Craen et al., 2007).

In Finland, Seikkula-Leino (2007) compared the cognitive skills of bilingual and non-bilingual students with their marks in Finnish (their L1) and found no differences between both groups in terms of their ability to obtain marks above, below or in line with their capacity. Another interesting study set in Finland was carried out by Bergroth (2006), who explored the impact of bilingual education on the development of the mother tongue by using the results in the matriculation examination at the end of secondary school as a reference point. The results of bilingual and non-bilingual students in the written composition in L1 were contrasted and no negative repercussions were detected.

In Spain, a country that, according to Coyle (2010: viii), "is rapidly becoming one of the European leaders in CLIL practice and research", Ramos et al. (2011) conducted a study in primary and secondary schools in Andalusia and concluded that the academic restriction on L1 in CLIL programs did not hinder its acquisition. Moreover, in primary education, CLIL students at state schools even outperformed their non-CLIL counterparts in some analytical tasks such as correcting spelling and punctuation mistakes, identifying prefixes and suffixes, and verb conjugations. As for secondary education results in state schools, the CLIL group surpassed their non-CLIL peers in understanding literary language, identifying literary authors and their works, and in giving a critical point of view. In the same vein, Pérez-Cañado (2017) analyzed data from three autonomous communities: Andalusia, Extremadura and the Canary Islands, and found that bilingual education does not hinder acquisition of L1.

In the Basque Country, the longitudinal study carried out by Merino and Lasagabaster (2018) on 285 secondary education students, revealed no differences between the CLIL and the non-CLIL group in the development of the two official languages, Spanish, and Basque. In turn, research by San Isidro and Lasagabaster (2018) set in Galicia yielded even more positive results, since, after two years of implementing CLIL, the CLIL students not only outperformed their nonCLIL peers in English, but also in the official languages, Spanish, and Galician. According to the authors this was a consequence of the pedagogical guidelines followed in CLIL schools, based on a multilingual approach to language learning. As for Castilla-La Mancha, the autonomous community where the present 
study is set, three main large-scale research projects were conducted on literacy acquisition in L1, two of them set in primary education (Nieto, 2018c, 2020) and one, on reading comprehension in L1 in secondary school students (Nieto, 2017). At primary school, no differences were detected between CLIL and nonCLIL learners in their literal and inferential reading comprehension, although the former scored significantly lower in critical reading. The detrimental critical reading acquisition in CLIL learners might be due to the fact that CLIL teaching methodology had a greater focus on providing students with reading strategies for literal and inferential comprehension in order to prepare them for the challenge of understanding academic texts in L2 (Nieto, 2018c). At secondary school, CLIL students significantly outperformed the non-CLIL group in literal and inferential reading, although this time, both groups were on par in terms of critical reading acquisition (Nieto, 2017), which means that although in primary school CLIL students lagged behind in critical reading, they caught up to their non-CLIL peers in secondary school, and additionally, significant benefits in literal and inferential reading were observed. This pattern is in keeping with research results of immersion programs expounded in this section.

As for written production in L1 in primary school, a differential achievement was detected between CLIL/non-CLIL learners in some areas: CLIL students significantly outperformed their peer in expressive richness and spelling, whereas the non-CLIL group was ahead in planning strategies, and in the use of text typologies (Nieto, 2020). In this context, this study intends precisely to get insight into written production development in L1 in secondary school, and therefore aims to provide a clearer picture on the evolution of development of literacy in L1 in CLIL throughout primary and secondary education.

\section{METHOD}

\subsection{Research questions}

Within this framework, this study aims to explore the acquisition of the mother tongue in bilingual (CLIL) secondary education, particularly, regarding the development of written production, which is an area that has received little attention so far. The research questions this study intends to answer are:

1. Does CLIL have a positive or negative impact on overall acquisition of written production in the mother tongue of secondary school students?

2. Are there any differences in acquisition of the four dimensions of written production considered: planning, use of text typologies, fluency, and accuracy, depending on whether CLIL/non-CLIL is implemented? 
3. Are there any differences in the acquisition of written production subskills between CLIL and non-CLIL students?

\subsection{Participants and context}

Participants were 4,675 13-14-year-olds in the $2^{\text {nd }}$ year of compulsory secondary education (henceforth 2CSE) enrolled at state secondary schools in CastillaLa Mancha (Spain), a monolingual autonomous community located in central Spain with a population of a little over 2 million and a total area of $79,409 \mathrm{~km}^{2}$. Participants were divided into two groups: the CLIL group, made up of 2,237 students enrolled in bilingual programs, and therefore receiving at least $50 \%$ of at least two content subjects through English, as well as English language teaching (EFL) itself; and the non-CLIL group, composed of 2,438 students in mainstream education, whose only means of learning English was through EFL, and the rest of their curriculum was taught in Spanish, their mother tongue. Those participating in the CLIL group had been enrolled in bilingual programs for at least two years, since the beginning of secondary education.

Although bilingual education had existed previously in the region with agreements between the Spanish Ministry of Education and the British Council in 1996, the bilingual programme of Castilla-La Mancha was created in 2005, through Order 07/02/2005 (DOCM 02/24/2005). This order has undergone various amendments, such as Decree 7/2014, of 1/22/2014 and Decree 47/2017. These last two amendments were inspired by seemingly contradictory policies: the former aimed to generalize implementation of bilingual programs at all schools in the region, while the intention behind the latter was for the administration to control the growth in the number of bilingual schools, in order to properly provide for all of them and guarantee adequate quality standards.

Nevertheless, the core elements of the program have not essentially changed since its inception, in terms of features such as promoting a methodology based on integrating content and foreign language learning, using the target language in all school environments, and participation in European projects and exchanges.

CLIL teachers, i.e. those who teach the content of their subjects such as Social Science, History or Biology in English must have a B2 CEFR level. Student access to bilingual programs is governed by the general admission rules common to all schools and depends on factors such as catchment area, number of siblings already enrolled at the school, income etc. Regulations prohibit selecting students on linguistic or academic grounds, and access is free and voluntary. The bilingual program in Castilla-La Mancha aims to be inclusive, comprehensive, and nonselective. However, as access is voluntary, the CLIL program might attract students who are more motivated or have a greater aptitude for English. Regarding the 
addition of new schools to the bilingual program, the educational administration announces official calls on a yearly basis for schools to apply to the program in the event they are prepared for implementing bilingual education, fundamentally in terms of their human resources, i.e., content can be taught by teachers with the required $\mathrm{B} 2$ level in the target language.

\subsection{Instruments}

The instrument used in this study was designed by the office of evaluation of Castilla-La Mancha and was made up of a scenario and a set of two tasks linked to a system of six subskills classified into four dimensions.

The scenario contained the stimulus "that forms the basis for generating writing content" Cushing (2009: 62) and was made up of both visual support -the painting "Guernica" by Picasso- and a short text describing the task. The students were told to imagine they were one of the characters in the picture and to write in the first person what happened on the day Guernica was bombed: their memories of that day, some events, what they did, thought and felt. In this way, students were provided with an engaging topic to write about and given some suggestions and ideas, in order to help them show their creativity, since "writers must be engaged enough in the task to find something to say" (Cushing, 2009: 91). Before writing the story (task 2) students had to write an outline that contained the main parts or events they planned to include (task 1). Both tasks were used to assess the following six subskills: 1) planning strategies, 2) use of text typologies (description, narration, dialogic fragments...), 3) expressive richness, 4) use of written vocabulary, 5) use of grammatical structures and (6) spelling and punctuation. The maximum possible score in the test was 12 points since every subskill was awarded up to 2 points. These subskills were included in four dimensions: a) planning strategies, b) use of text typologies, c) fluency (expressive richness and use of written vocabulary) and d) accuracy (use of grammatical structures and spelling). Students had 30 minutes to perform the tasks.

\subsection{Data analysis and presentation}

Results were analyzed using IBM's Statistical Package for Social Science (SPSS) software. The goodness of fit using the Kolmogorov-Smirnov Test was high (0.819), and since The Kolmogorov-Smirnov Test showed the sample had a normal distribution, further t-tests were run to compare the results of CLIL and 
non-CLIL students with regard to acquisition of subskills and dimensions of written production in their mother tongue (Spanish). To better understand and compare these results, they are presented on a 0 to 10 scale.

\section{RESULTS}

\subsection{Overall development of written production in mother tongue of secondary school students}

The overall results in the acquisition of written production in the mother tongue $(\mathrm{CLIL}=6.23$; non-CLIL=4.75) showed CLIL students significantly $(\mathrm{p}<0.05)$ outperformed their non-bilingual peers (Graph 1).

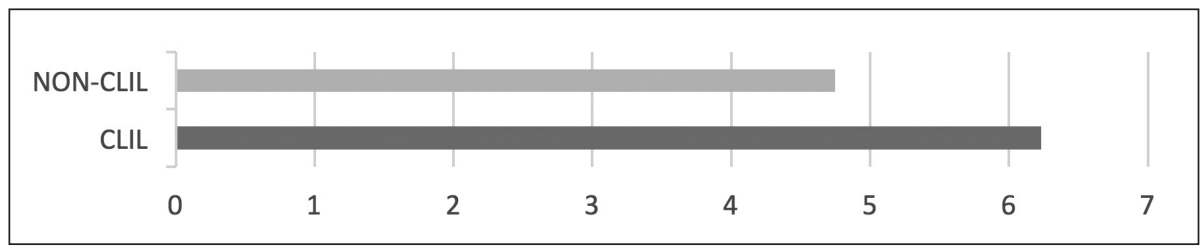

Graph 1. Overall acquisition of written production of CLIL and non-CLIL students.

The first observation which derives from these data is the low level of mainstream students when it comes to evaluate their competence in written production in their mother tongue. Thus, although the results for the bilingual group were not very high (6.23 out of 10$)$, the score of the non-CLIL group was significantly lower, 4.75 out of 10 . Using school standards, the non-CLIL group, with less than 5 points out of 10 would fail in written production in L1.

\subsection{Acquisition of dimensions of written production}

As shown in Graph 2, CLIL students scored significantly higher than their non-CLIL counterparts in all the dimensions of written production assessed: planning strategies $(C L I L=5.4$; non-CLIL $=4)$, text typology $(C L I L=6.1$; nonCLIL=5), fluency (CLIL=6.77; non-CLIL=5.3) and accuracy (CLIL=6.175; nonCLIL=4.5). 


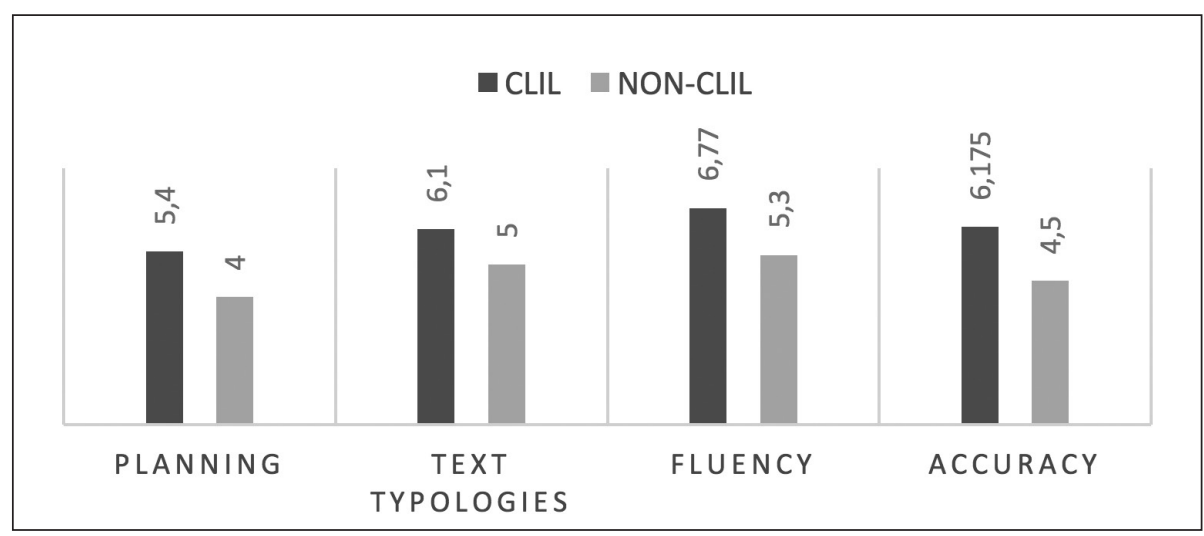

Graph 2. Results of CLIL and non-CLIL students by dimensions of written production.

Both groups showed lowest results in planning $(\mathrm{CLIL}=5.4$; non- $\mathrm{CLIL}=4)$, while their highest ones were recorded in fluency $(\mathrm{CLIL}=6.77$; non-CLIL=5.3). The greatest differences between the groups were detected in accuracy (CLIL=6.175; non-CLIL=4.5), which means that CLIL students were remarkably more advanced when writing texts in their mother tongue with the correct spelling and grammar. The CLIL group obtained scores above 5 points out of 10 in all the dimensions of written production, whereas the non-CLIL recorded below 5 points out of 10 in two of them: planning their written productions and writing accurate texts in terms of correct use of grammar and spelling. The non-CLIL group "passed" in following the conventions of the given text typology, but only with just 5 points out of 10 .

\subsection{Development of written production subskills}

Considering the subskills used for assessing written production in the mother tongue individually, the scores of CLIL students were seen to be higher in all of them (planning, CLIL=5.4; non-CLIL=4; text typologies CLIL=6.1; nonCLIL=5; vocabulary, CLIL7.1; non-CLIL=5.6; expressive richness, $C L I L=6.45$; non-CLIL=4.9; grammar, $C L I L=6.95$; non-CLIL=5.45; spelling CLIL=5.4; nonCLIL=3.55). In all cases, $\mathrm{p}<0.05$ which means differences in favor of the CLILgroup were significant in all subskills considered. 


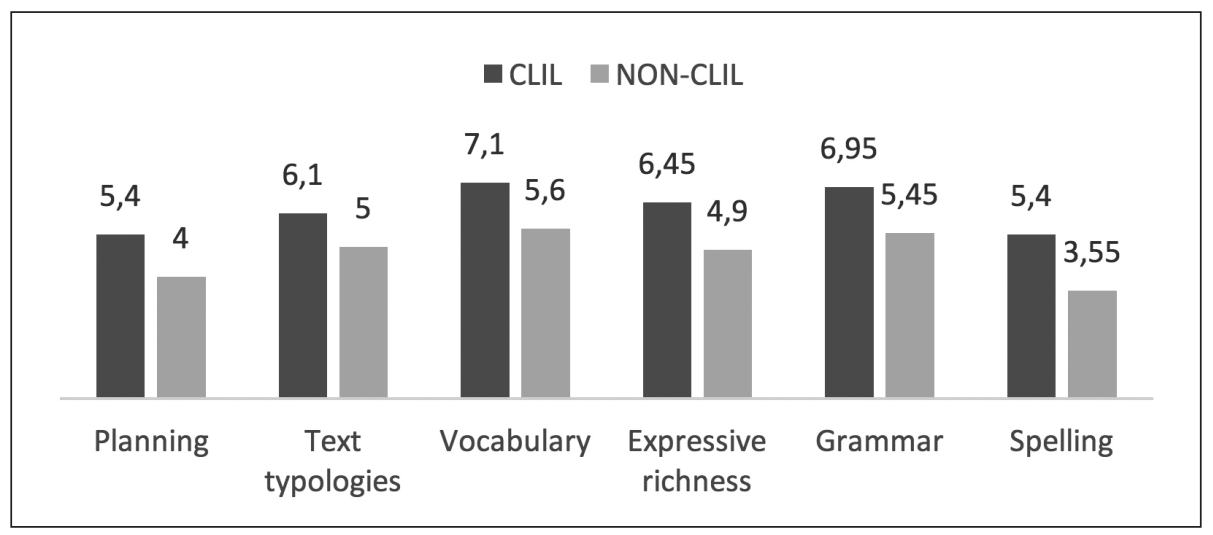

Graph 3. Results of CLIL and non-CLIL students in the subskills of written production.

The CLIL group scored above 5 out of 10 in all subskills considered. The areas in which the CLIL group got higher scores were vocabulary $(\mathrm{CLIL}=7.1$; nonCLIL=5.6) and grammar (CLIL=6.95; non-CLIL=5.45). In contrast, the lowest score of the CLIL cohort was 5.4, which was obtained in planning and spelling. The non- CLIL group, in turn, scored below 5 points out of 10 in 3 subskills: planning (non-CLIL=4), expressive richness (non-CLIL=4.9) and spelling (nonCLIL=3.55), and their highest score was 5.6 (recorded in vocabulary).

The most difficult part of the writing tasks was using correct spelling, since both groups received their lowest score in this subskill $(\mathrm{CLIL}=5.4$; non-CLIL=3.55). Interestingly, differences favoring the CLIL group were most marked in precisely in this subskill, which indicated that bilingual education had a special influence on the areas of writing in which mainstream students performed lower.

\section{DISCUSSION}

The main aspects to be foregrounded in the discussion section will be: (1) CLIL had a positive effect on developing written production in L1, (2) the areas which most benefited from CLIL were: spelling, planning and expressive richness, and (3) CLIL had a more positive impact on the most demanding areas of writing. 


\subsection{CLIL positively impacted acquisition of written production in the mother tongue}

This research shows that, although CLIL students received lower academic exposure to their mother tongue than their counterparts, this limited use of their L1 did not hinder its acquisition, but promoted it, since CLIL students acquired a significantly higher command of written production skills. This somewhat surprising finding, is, however, coherent with other studies on bilingual education, and particularly with research conducted on Canadian immersion programs, where the presence of the mother tongue at school is far more limited than in this study (Turnbull et al., 2003). Cummins' (1979) theory on Common Underlying Proficiency, and Genesse and Jared's (2008) transfer hypothesis explained these findings due to the fact that, since most of linguistic and cognitive tasks are common across languages, the metalinguistic knowledge acquired in one language can be transferred to another language or languages.

In European settings, more evidence in keeping with the results of this study can be found in previous research in Finland and Belgium (Bergroth, 2006; Lecocq et al., 2004; Van de Craen et al., 2007), and also in Spain (San Isidro and Lasagabaster, 2018). Thus, San Isidro and Lasagabaster (2018), in their research set in the Spanish autonomous community of Galicia detected that the CLIL program not only helped acquisition of English (the L3 of instruction), but also development of Spanish and Galician (the L1 and L2). The paradox bilingual education poses, in helping the mother tongue develop (even if these programs imply limited academic exposure to L1) is explained by the authors as a by-product of the multilingual approach to language learning implemented in these settings "which might make students more aware of how languages work" (San Isidro and Lasagabaster, 2018: 15), an elucidation that might also be applied to this research.

Additionally, Reilly and Medrano (2009) observed that CLIL students displayed enhanced higher-order cognitive skills and, in the same vein, Marsh (2002: 201) pointed out the potential CLIL has in the "development of learning strategies and skills, which are related to broader cognitive applications" (Marsh, 2002: 201). This so called "added value" CLIL provides (Marsh, 2002), in terms of acquiring cognitive strategies, might account for the higher written production performance displayed by students in this study.

\subsection{The areas more benefitted by CLIL were: spelling, planning and expressive richness}

The areas of written production in which CLIL students outperformed their non-bilingual peers by the greatest margin were spelling, planning and expressive 
richness. Spelling was, without question, the most difficult task in the test, since non-CLIL students scored 3.55 out of 10, and although the results of the CLIL group were not very high (5.4 out of 10), the difference between both groups was greater than in other areas considered when assessing written production. This finding is in line with the study by Ramos et al. (2011) in which profiency in the mother tongue of CLIL and non-CLIL students (11-12-years old ) was compared and the CLIL group significantly outperformed their non-CLIL peers in correcting spelling and punctuation errors. Additionally, this advantage of CLIL students in spelling is also in keeping with data collected in primary education (Nieto, 2020) in the same autonomous community (Castilla-La Mancha) the present study is set. As this skill in particular was developed in CLIL students, this could be related to how CLIL helps to develop metalinguistic awareness (Marsh, 2009), and so, CLIL students might have become more aware of spelling, due to the difficulty it poses in English. This ability, acquired when learning the L2 through CLIL, could have been transferred to their mother tongue, as suggested by Cummins (1979) in his interdependence theory.

CLIL students also showed better planning skills than their mainstrem peers. This was a difficult area for both groups, and non-CLIL students recorded a score of 4 out of 10 , which by school standards would mean failing. Planning strategies is a paramount thinking skill in the writing process and helps improve the quality of a text. The fact that CLIL students outperformed their bilingual peers in their planning abilities is in keeping with previous studies which revealed CLIL helps cognitive skills expand further (Mehisto and Marsh, 2011). Similarly, a study by Nieto (2016b) concluded CLIL students enrolled at secondary school displayed better learning strategies. They were ahead in their learning to learn competence when compared to their non-CLIL counterparts, including their ability to plan, organise, structure, classify and synthesize. However, this finding contrasts with data collected in primary education (Nieto, 2020), which showed CLIL students lagged significantly behind in planning strategies. This negative effect observed in primary education seems to have been surmonted by CLIL students in secondary school, educational stage, in which, according to Reilly and Medrano (2009), the benefits of CLIL are more widely displayed.

Another area in which the performance of CLIL students was remarkable was in the expressive richness shown in their texts. This finding is in keeping with Nieto's (2020) study which recorded CLIL primary school students aged 9-10 significantly outperformed their non-CLIL peers in their expressive richness. This outcome concurs with most research conducted for ascertaining the impact CLIL has on second language acquisition, and one benefit CLIL is claimed to have is precisely its potential to enhance fluency in the second language (Pérez-Cañado, 2012; Ruiz de Zarobe, 2015).

Although less marked than in spelling, planning and fluency, differences 
in favour of the CLIL group were also significant in the other areas under consideration. In this regard, CLIL students showed better command in writing texts using complex sentences without making grammar mistakes. They were also ahead in adapting their texts to the appropiate text typology and in using varied vocabulary for expressing their ideas.

\subsection{CLIL most positively impacted the most demanding areas of writing}

Although CLIL students significantly outperformed their monolingual peers in all the areas under consideration, it should be mentioned that differences between the CLIL and the non-CLIL group were greatest in the most difficult subskills. The results from this study showed that the lower the scores of both groups were, the more ahead CLIL students were. The subskills in which the students had the lowest performance in were, in this order: spelling, planning and expressive richness, and it was these very subskills where the greatest differences in favour of CLIL students were detected.

Evidence of this phenomenon can be found in previous research in which CLIL students were most ahead of their non-CLIL peers in the most difficult tasks. Thus, Prieto-Arranz et al. (2015:133), when evaluating acquisition of oral comprehension in the target language, concluded that "CLIL programs had a positive impact on cognitively demanding listening activities", and Pérez-Cañado and Lancaster (2017:9) observed that "CLIL students achieved significantly higher scores on complex listening tests". Although both these studies focused on determining what impact CLIL had on listening and not on writing, and the language they evaluated was L2, and not L1, their findings can be applied to this study and may reveal a particular trend which shows CLIL students to be better at solving more cognitively demanding tasks. Another study, which explored learning strategies of CLIL and non-CLIL secondary school students, seemed to concur with this pattern, since differences in favour of CLIL participants were proportionally greater in the acquisition of the most complex learning tasks connected to higher order thinking skills (Nieto, 2016b). The tenets of authors such as Bialystok et al. (2007), and Mehisto and Marsh (2011) concerning the potential CLIL has in enhancing problem-solving skills, cognitive functioning, and higher order thinking seem to endorse this hypothesis.

\section{CONCLUSION}

The main conclusions that can be drawn from the data analyzed in this study are as follows. 
CLIL had a significantly positive effect on the development of written skills in the mother tongue, even if, academically speaking, students in bilingual education were less exposed to L1 than their non-CLIL counterparts. Although this finding may seem paradoxical (less academic contact with L1 produces better performance), it is coherent with research conducted in even more immersive bilingual education environments in which the mother tongue as a language for school instruction is even more restricted (Lecocq et al., 2004; Turnbull et al., 2003). Both theories, the interdependence theory and the CUP (Cummins, 1979), which champions the idea that skills acquired in one language can be transferred and applied in the language learning process of another language might explain this outcome. Therefore, the main conclusion to be drawn from this theory is that bilingual education could benefit both L1 and L2 acquisition, and the findings of the present study seem to endorse this hypothesis.

Furthermore, CLIL had a positive effect on all subskills in written production, but especially in the most demanding areas of writing: spelling, planning and expressive richness. Thus, the trend in CLIL which showed students performed higher in the most difficult or challenging tasks (Pérez-Cañado and Lancaster, 2017; Prieto-Arranz et al., 2015) has also been recorded in this study.

The aim of this research was to provide an overview of acquisition of written production in the mother tongue within the bilingual program type CLIL established in the Spanish autonomous community of Castilla-La Mancha in state secondary schools, and results have shown CLIL students had the opportunity to develop their written skills in L1 even more than those in regular programs did. It must be stressed that although access to this bilingual program is voluntary, selecting students based on academic or linguistic grounds is strictly forbidden, since the program aims to be inclusive and non-selective. Nevertheless, more research is needed, to determine what impact CLIL has on L1 development. In particular quantitative research, controlling additional variables and qualitative approaches, by means of classroom observations and interviews, would also be welcome to assess what impact teaching methodology has on the development of written skills in L1 and L2, and on acquiring transferable skills and learning strategies, among other key issues.

\section{ACKNOWLEDGMENTS}

This study has been funded by the Spanish Ministry of Economy and Competitiveness, MINECO (Reference: RTI2018-093390-B-I00). Special thanks go to the Castilla-La Mancha Office of Evaluation for their invaluable help. 


\section{REFERENCES}

Bergroth, Mari. (2006). Immersion students in the matriculation examination Three years after immersion. In K. Björklund, M. Mård-Miettinen, M. Bergström, \& M. Södergård (Eds.), Exploring Dual-Focussed Education, integrating Language and Content for Individual and Societal Needs (pp. 123134). Vaasa: University of Vaasa.

Bialystok Ellen, Craik, I.M. Fergus, \& Freedman, Morris. (2007). Bilingualism as a protection against the onset of symptoms of dementia. Neuropsychologia, 45(2), 459-464.

Coyle, Do. (2010). Foreword. In D. Lasagabaster, \& Y. Ruiz de Zarobe (Eds.), CLIL in Spain: Implementation, results and teacher training (pp. vii-viii). Newcastle-upon-Tyne: Cambridge Scholars Publishing.

Coyle, Do; Hood, Philip \& Marsh, David. (2010). CLIL: Content and Language Integrated Learning. Cambridge, United Kingdom: Cambridge University Press.

Cummins, Jim. (1979). Linguistic Interdependence and the Educational Development of Bilingual Children. Review of Educational Research, 49(2), 222-251. DOI: $10.2307 / 1169960$

Cushing Weigle, S. (2009). Assessing writing. Cambridge, UK: Cambridge University Press.

Dalton-Puffer, Christiane, Nikula, Tarja \& Smit, Ute. (2010). Charting policies, premises and research on Content and Language Integrated Learning. In Ch. Dalton-Puffer, T. Nikula \& U. Smit (Eds.), Language use and language learning in CLIL Classrooms (pp. 1-22). Amsterdam, Netherlands: John Benjamin Publishing.

Fernández-Fontecha, Almudena. (2010). First steps of CLIL in a Spanish Monolingual Community. In D. Lasagabaster \& Y. Ruiz de Zarobe (Eds.), CLIL in Spain: Implementation, results and teacher training (pp. 79-94). Newcastle upon Tyne: Cambridge Scholars Publishing.

García-Fernández, Beatriz, Nieto Moreno de Diezmas, Esther, \& Ruiz-Gallardo, José Reyes. (2017). Mejorar la motivación en ciencias con enseñanza CLIL. Un estudio de caso. Enseñanza de las Ciencias, no Extraordinario, 2625-2630.

Genesee, Fred. (2007). Literacy outcomes in French immersion. Encyclopedia of Language and Literacy Development (pp. 1-8). London, UK: Canadian Language and Literacy Research Network.

Genesee, Fred, \& Jared, Debra. (2008). Literacy Development in Early French Immersion Programs. Canadian Psychology, 49(2), 140-147. doi:10.1037/07085591.49.2.140

Grisaleña, Jesús, Alonso, Esmeralda, \& Campo, Alejandro. (2009). Enseñanza 
plurilingüe en centros de educación secundaria: análisis de resultados. Revista Iberoamericana de Educación, 49(1), 1-12.

Krashen, Stephen. (1988). Second Language Acquisition and Second Language Learning. Prentice-Hall International.

Lapkin, Sharon, Hart, Dough, \& Turnbull, Miles. (2003). Grade 6 French immersion students' performance on largescale reading, writing, and mathematics tests: Building explanations. Alberta Journal of Education, 49, 6-23.

Lasagabaster, David \& Sierra, Juan Manuel. (2009). Immersion and CLIL in English: More differences than similarities. ELT Journal, 63(4), 367-375.

Lecocq, Katia, Mousty, Philippe, Kolinsky, Regine, Goetry, Vincent, Morais, José, \& Alegria, Jesus. (2004). Evaluation des programmes d'immersion en communauté française: une étude longitudinale comparative du développement des compétences linguistiques d'enfants francophones immergés en néerlandais. ULB: Ministère de la Communauté française.

Madrid, Daniel. (2011). Monolingual and Bilingual Students' Competence in Social Studies. In D. Madrid \& S. Hughes (Eds.), Studies in Bilingual Education (pp. 195-222). Bern: Peter Lang.

Marsh, David. (2002). CLIL/EMILE-The European dimension. Actions, trends and foresight potential. Finland: Unicom, Continuing Education Centre.

Marsh, David. (2009). CLIL. An interview with Professor David Marsh. IH Journal of Education and Development, 26. http://ihjournal.com/content-andlanguage-integrated-learning

Mehisto, Peeter, \& Marsh, David. (2011). Approaching the Economic, Cognitive and Health benefits of Bilingualism: Fuel for CLIL. In Y. Ruiz de Zarobe, J. Sierra \& F. Gallardo del Puerto (Eds.), Content and Foreign Language Integrated Learning (pp. 21-48). Bern: Peter Lang.

Merino, Jon Ander, \& Lasagabaster, David. (2018). CLIL as a way to multilingualism. International Journal of Bilingual Education and Bilingualism, 21, 79-92.

Navarro Pablo, Macarena., \& García Jiménez, Eduardo. (2018). Are CLIL students more motivated? An analysis of affective factors and their relation to language attainment. Porta Linguarum, 29, 71-90.

Nieto Moreno de Diezmas, Esther. (2012). CLIL and the development of emotional competence. Miscelanea, a Journal of English and American studies, 45, 53-73.

Nieto Moreno de Diezmas, Esther. (2016a).The impact of CLIL on the acquisition of L2 competences and skills in primary education. International Journal of English Studies (IJES), 16(2), 81-101.

Nieto Moreno de Diezmas, Esther. (2016b). The impact of CLIL on the 
acquisition of the learning to learn competence in secondary school education in the bilingual programmes of Castilla-La Mancha. Porta Linguarum, 25, 2134.

Nieto Moreno de Diezmas, Esther. (2017). How does CLIL affect the acquisition of reading comprehension in the mother tongue? A comparative study in secondary education. Investigaciones sobre lectura, 8, 7-26.

Nieto Moreno de Diezmas, Esther. (2018a). The Acquisition of L2 Listening Comprehension Skills in Primary and Secondary Education Settings: A Comparison between CLIL and non-CLIL Student Performance. RLA. Revista de lingüistica teórica y aplicada, 56(2), 13-34. https://doi.org/10.4067/s071848832018000200013

Nieto Moreno de Diezmas, Esther. (2018b). Exploring CLIL contribution towards the acquisition of cross-curricular competences: a comparative study on digital competence development in CLIL. Revista de lingüistica y lenguas aplicadas, 13, 75-85.

Nieto Moreno de Diezmas, Esther. (2018c). Adquisición de la lectura en L1 en programas bilingües de Educación Primaria. Un estudio comparativo. Ocnos, 17(1), 43-54.

Nieto Moreno de Diezmas, Esther. (2020). Literacy Development in L1 in Bilingual Education: Evidence from Research on CLIL in Primary School. In M. Gómez-Parra, \& C. Huertas Abril (Eds.), Handbook of Research on Bilingual and Intercultural Education (pp. 383-407). Hershey, PA: IGI Global. doi:10.4018/978-1-7998-2588-3.ch016

Nieto Moreno de Diezmas, Esther \& Hill, Thomas Matthew. (2019). Social Science Learning and Gender-Based Differences in CLIL. A Preliminary Study. Estudios de lingüistica inglesa aplicada (ELIA), 19, 177-204. DOI: http://dx.doi.org/10.12795/elia.2019.i19.08

Pérez Cañado, María Luisa. (2012). CLIL research in Europe: Past, present, and future. International Journal of Bilingual Education and Bilingualism, 15(3), 315-341.

Pérez-Cañado, María Luisa. (2017). The effects of CLIL on L1 and content learning: Updated empirical evidence from monolingual contexts. Learning and Instruction. DOI: 10.1016/j.learninstruc.2017.12.002

Pérez-Cañado, María Luisa, \& Lancaster, Nina. (2017). The effects of CLIL on oral comprehension and production: A longitudinal case study. Language, Culture, and Curriculum, 30(3), 300-316.

Pérez-Cañado, María Luisa, \& Ráez Padilla, Juan. (2015). Introduction and overview, in D. Marsh, M.L. Pérez-Cañado \& J. Ráez Padilla (Eds.), CLIL in action: Voices from the classroom (pp. 1-12). Newcastle upon Tyne: Cambridge Scholars Publishing. 
Pérez-Vidal, Carmen. (2013). Perspectives and Lessons from the Challenge of CLIL Experiences. In C. Abello-Contesse, P. M. Chandler, M. D. LópezJiménez, \& R. Chacón-Beltrán (Eds.), Bilingual and Multilingual Education in the $21^{\text {st }}$ Century. Building on Experience (59-82). Bristol: Multilingual Matters. Prieto-Arranz, José Igor, Rallo Fabra, Lucrecia, Calafat-Ripoll, Caterina., \& Catrain González, Magdalena. (2015). Testing progress on receptive skills in CLIL and non-CLIL contexts. In M. Juan-Garau \& J. Salazar Noguera (Eds.), Content-based language learning in multilingual educational environments (123137). Amsterdam: Springer.

Ramos García, Ana María, Ortega, José Luis, \& Madrid, Daniel. (2011). Bilingualism and Competence in the Mother Tongue, in D. Madrid \& S. Hughes (Eds.), Studies in Bilingual Education (135-156). Bern: Peter Lang.

Reilly, Teresa, \& Medrano, María Pilar. (2009). MEC/British council Bilingual project. Twelve years of bilingual education and a smooth transition into secondary. In E. Dafouz \& M.C. Guerrini (Eds.), CLIL across educational levels (59-70). Richmond Publishing.

Ruiz de Zarobe, Yolanda. (2015). The effects of implementing CLIL in education. In M. Juan-Garau, \& J. Salazar-Noguera (Eds.), Content-Based Language Learning in Multilingual Educational Environments (pp. 51-67). Berlin: Springer.

San Isidro, Xavier, \& Lasagabaster, David. (2018). The impact of CLIL on pluriliteracy development and content learning in a rural multilingual setting: A longitudinal study. Language Teaching Research DOI:10.1177/1362168817 754103journals.sagepub.com/home/ltr

Seikkula-Leino, Jaana. (2007). CLIL learning: Achievement levels and affective factors. Language and Education, 21 (4), 328-341.

Sierra, Juan Manuel, Gallardo del Puerto, Francisco, \& Ruiz de Zarobe, Yolanda. (2011). Good practice and future actions on CLIL: Learning and Pedagogy, in Y. Ruiz de Zarobe, J. Sierra \& F. Gallardo del Puerto (Eds.), Content and Foreign Language Integrated Learning: Contributions to Multilingualism in European Contexts (pp. 317-338). Bern: Peter Lang.

Stohler, Ursula. (2006). The acquisition of knowledge in bilingual learning: an empirical study on the role of language in content learning. VIEWZ Vienna English Working Papers, 15(3), 41-46.

Swain, Merrill, \& Lapkin, Sharon. (1982). Evaluating bilingual education: A Canadian case study. Clevedon, UK: Multilingual Matters.

Tobin, Nicole, \& Christian Abello-Contesse. (2013). The use of native assistants as language and cultural resources in Andalusia's bilingual schools, in C. AbelloContesse, P. M. Chandler, M. D. López-Jiménez \& R. Chacón-Beltrán (Eds.), Bilingual and multilingual education in the 21st century. Building on experience (231-255). Bristol: Multilingual Matters. 
Turnbull, Miles, Hart, Dough, \& Lapkin, Sharon. (2003). Grade 6 French Immersion Students' Performance on Large-Scale Reading, Writing, and Mathematics Tests: Building Explanations. Alberta Journal of Education, 49, 6-23.

Van de Craen, Piet, Mondt, Katrien, Allain, Laure, \& Gao, Ying. (2007). Why and How CLIL Works. An Outline for a CLIL Theory. VIEWS Vienna English Working Papers, 18(3), 70-78. 